\title{
Studies on the Cellular Site of Action of Macrophage RNA-Antigen Complexes ${ }^{1}$
}

\author{
Sandra L. White ${ }^{2}$ and Arthur G. Johnson \\ Department of Microbiology, The University of Michigan, \\ Ann Arbor, Michigan 48104
}

Received May 13, 1975

\begin{abstract}
Nonadherent spleen cell populations exposed in vitro to ribonucleic acid-rich preparations from mouse macrophages that had been incubated with human $\gamma$-globulin (RNA : HGG) were able to produce specific antibody, as measured by rosette-forming cells, in lethally irradiated $(800 \mathrm{R})$, reconstituted, syngeneic mice. Exposure of the RNA to anti-HGG serum abrogated its ability to initiate antibody synthesis, as did monospecific anti-human $\gamma$ chain and anti-human $\kappa$ chain serum. Normal rabbit serum, anti-bovine albumin serum, anti-human $\mu$ chain or anti-human $\lambda$ chain serum, when substituted for anti-HGG serum had no effect. Thus, the presence of both $\gamma$ heavy chains and $\kappa$ light chains of the antigen in the RNA moiety was indicated. Although both an adherent and a nonadherent cell were required by HGG to stimulate rosetteforming cells in irradiated mice, the need for the adherent cell was eliminated when RNA : HGG was substituted for HGG. In addition, anti- $\theta$-treated bone marrow cells exposed to the RNA:HGG were capable of rosette-cell formation, suggesting that RNA attachment converted a $T$ cell-dependent antigen to a $T$ cell-independent antigen.
\end{abstract}

\section{INTRODUCTION}

Interpretation of the above-normal antibody levels resulting following in vitro addition of antigen to peritoneal exudate cells (PEC) ${ }^{3}$ isolated from uninjected mice and transfer of the washed cells or an RNA-rich extract into syngeneic mice has aroused controversy with regard to whether attachment of antigen to a unique macrophage RNA is a necessary prerequisite to antibody formation $(1,2)$. Irrespective of the interpretation, however, there is no question that this procedure results in an excellent adjuvant action by the transferred $\mathrm{PEC}$, and the fact that

1 This research was supported by U.S. Public Health Service Grant No. AM 14273. Presented in part to the 75th Annual Meeting of the American Society of Microbiologists, New York, N.Y., May 1975.

2 Supported by Ford Foundation Advanced-Study Fellowship. Taken in part from a dissertation submitted to the Graduate School, The University of Michigan, Ann Arbor, Mich., in partial fulfillment of the requirements for the Doctor of Philosophy degree. Present address: Department of Microbiology, Howard University Medical School, Washington, D.C. 20059.

3 Abbreviations used in this paper: PEC, peritoneal exudate cells; BSA, bovine serum albumin; HGG, human $\gamma$-globulin; BME, Eagle's basal medium; HBSS, Hanks' balanced salt solution; RFC, rosette-forming cells; PFC, plaque-forming cells, SRBC, sheep red blood cells; NASC, nonadherent spleen cell; ASC, adherent spleen cell; NRS, normal rabbit serum; n-RNA, RNA extracted from normal macrophages; RNA:HGG, RNA extracted from macrophages sensitized to HGG; PBS, phosphate-buffered saline. 
RNA-rich materials can be extracted from such cells and have been shown to confer immunogenicity on otherwise unresponsive hosts (3-5) is worthy of mechanistic definition. Accordingly, previous studies from this laboratory (6) have shown that a 4S RNA-rich fraction, isolated by phenol extraction from mouse peritoneal exudate cells exposed in vitro to antigen, was capable of inducing rosetteforming cells (RFC) and antibody production to bovine $\gamma$-globulin (BGG) on injection into syngeneic mice. The antigen contamination of this RNA, as determined isotopically, was below $10^{-11} \mathrm{~g} / 0.1 \mathrm{~g}$ of RNA. It could not be concluded which cell type the RNA-rich fraction stimulated, whether antibody synthesis resulted from trace amounts of antigen combined with a nucleic acid acting as an adjuvant (7) or whether the RNA itself was the induced mediator. Consequently the experiments described herein were designed to obtain information on these questions. The data are interpreted in support of the hypothesis that a minute amount of what was originally a thymus-dependent antigen remains attached to the RNA and that this antigen in RNA complex form is capable of stimulating directly the bone marrow-derived cell in the nonadherent cell population.

\section{MATERIAL AND METHODS}

Animals. BALB/Aj mice were inbred in our laboratory. The mice were fed Purina mouse chow and water ad libitum.

Antigen. Human $\gamma$-globulin (HGG), Fraction II, was obtained from Miles Pentex Laboratorics, Kankakce, Ill. Chromatographically purified 7S IIGG was purchased from Mann Research, New York, N.Y.

Homoribopolynucleotides. Polyadenylic acid (poly $(\mathrm{A})$ ), potassium salt (Lot 11-57-301) and polyuridylic acid (poly(U)), ammonium salt (Lot 11-64-308) were purchased from Miles Laboratories, Elkart, Ind. Each polymer was stored at $-20^{\circ} \mathrm{C}$ at a concentration of $3 \mathrm{mg} / \mathrm{ml}$ in $\mathrm{PBS}, \mathrm{pH}$ 7.2. Polymers were complexcd in vitro to form poly $(\mathrm{A}: \mathrm{U})$ by mixing equal volumes of the polynucleotides for $10 \mathrm{~min}$ at room temperature, just prior to use.

Endotoxin. Serratia marcesens endotoxin, SMTCA-AA, prepared by the Boivin procedure, was obtained from Dr. A. Nowotny, Temple University, Philadelphia, $\mathrm{Pa}$.

Enzymes. Nuclease-free pronase (Lot 023032), B grade, was obtained from Calbiochem, Los Angeles, Calif. It was self-digested for $1 \mathrm{hr}$ at $37^{\circ} \mathrm{C}$. Proteolytic activity was verified by solubilization of $\mathrm{HGG}$, as measured by loss in capacity to be precipitated by anti-HGG.

Antisera. Monovalent goat anti-human IgG (Lot 204F043) and goat anti-human IgM (Lot 205F052) were obtained from Kallestad Laboratories, Inc., Chaska, Minn. These sera titered $1: 16$ and $1: 8$, respectively, when assayed by double diffusion in agar for their ability to form precipitin lines with a $1-\mathrm{mg} / \mathrm{ml}$ antigen solution. A 1:4 dilution of the antisera contained $1 \mathrm{mg} / \mathrm{ml}$ of protein. Rabbit antiBSA (Lot 14) was obtained from Miles Pentex Laboratories.

Anti-HGG serum was prepared by injecting rabbits intramuscularly weekly for 4 weeks with $0.25 \mathrm{ml}$ of a $10 \mathrm{mg} / \mathrm{ml}$ suspension of $\mathrm{HGG}$ in $0.15 \mathrm{M} \mathrm{NaCl}$ and Freund's complete adjuvant (FCA). One week later the rabbits were bled and at weeks 6 and 8 they were reinjected subcutaneously with $1 \mathrm{mg}$ of HGG. One week after each reinjection the rabbits were bled again, and sera from all bleedings 
were pooled, absorbed with $\mathrm{SRBC}$ and inactivated at $56^{\circ} \mathrm{C}$ for $30 \mathrm{~min}$ prior to use. The serum had a hemagglutination titcr of $1: 70,000$. Anti- $\theta$ serum was prepared in AKR mice with $\mathrm{C}_{3} \mathrm{H}$ thymocytes by using the method of Reif and Allen (8).

Irradiation. BALB/Aj mice 9-12 weeks old were exposed to $800 \mathrm{R}$ whole body irradiation at a distance of $71 \mathrm{~cm}$ from an $\mathrm{X}$-ray source delivering $66.7 \mathrm{R} / \mathrm{min}$, $(\mathrm{kVolts}=250 ;$ filter, $0.5 \mathrm{~mm} \mathrm{Cu}+1 \mathrm{~mm} \mathrm{~A})$.

$P E C$ isolation. Macrophages (used synonymously with $\mathrm{PEC}$ ) were isolated by a modification of the method of Gallily and Feldman (9). BALB/Aj mice, 1620 weeks old were injected with $3.0 \mathrm{ml}$ of thioglycollate medium. Five days later the cells in the peritoneal cavity were washed out with $10.0 \mathrm{ml}$ of Hanks' balanced salt solution (HBSS), $\mathrm{pH} 7.2$, containing penicillin, streptomycin and heparin, 100 units, $50 \mu \mathrm{g}$, and $5 \mathrm{USP} / \mathrm{ml}$ units, respectively. Purification was achieved by centrifugation at $900 \mathrm{rpm}$ for $10 \mathrm{~min}$, removal by aspiration of the supernatant fluid and the top 1-2 mm of packed cells, resuspension of the pellet in $10 \mathrm{ml}$ of HBSS, pH 7.2 , and repetition of the centrifugation twice. The pellet was suspended in five parts of $0.2 \% \mathrm{NaCl}$ for $20 \mathrm{sec}$ to lyse the red cells, immediately diluted 10 -fold with $\mathrm{BME}$ and counted in a hemocytometer. The cell population was routinely greater than $95 \%$ macrophages and contained approximately $1 \%$ lymphocytes.

In vitro incubation of macrophages with antigen. Incubation with antigen was carried out for $2 \mathrm{hr}$ in screw-cap 50 -ml Erlenmeyer flasks in a $37^{\circ} \mathrm{C}$ shaking waterbath. Cells were suspended at a concentration of $5 \times 10^{z}$ cells $/ \mathrm{ml}$ and incubated with antigen at a cell : antigen ratio of $2.5 \times 10^{7}$ cells: $0.5 \mathrm{mg}$ of HGG. After incubation, cells were washed twice with BME and centrifuged for 20 min at 1000 rpm. The washed, packed cell pellet was frozen in an acetone-dry ice bath and stored at $-20^{\circ} \mathrm{C}$ prior to RNA extraction. Macrophages from which normal RNA was to be extracted were treated as above except that, after harvesting and washing, the cells were frozen and stored rather than being incubated with antigen.

Isolation of RNA from macrophages. Purified macrophages which had been accumulated and stored at $-20^{\circ} \mathrm{C}$ were thawed in two volumes of buffer $(0.15 \mathrm{M}$ $\mathrm{NaCl}, 0.1 \mathrm{M}$ EDTA containing $10^{-3} \mathrm{M} \mathrm{MgCl}$ and $0.5 \%$ SDS). The cells were then homogenized for 20 strokes in a glass homogenizer, an equal volume of freshly distilled water-saturated phenol added, and the mixture shaken for $10 \mathrm{~min}$ at $25^{\circ} \mathrm{C}$ and stirted for $3 \mathrm{~min}$ at $63^{\circ} \mathrm{C}$. The aqueous phase was removed after centrifugation at $1000 \mathrm{rpm}$ for $15 \mathrm{~min}$. An equal volume of choloroform-isoamyl alcohol (24:1, $\mathrm{v} / \mathrm{v}$ ) was added to deproteinize the aqueous phase and, after shaking for $10 \mathrm{~min}$, the mixture was centrifuged at $1000 \mathrm{rpm}$ for $10 \mathrm{~min}$. This deproteinization was repeated three times. The resulting aqueous phase was treated with $1 \mathrm{mg}$ of selfdigested Pronase $/ \mathrm{ml}$ of solution for $60 \mathrm{~min}$ at $25^{\circ} \mathrm{C}$. The Pronase-treated solution was deproteinized again with chloroform-isoamyl alcohol and finally precipitated with cold absolute ethanol. Precipitation was allowed to proceed for $24 \mathrm{hr}$ at $-20^{\circ} \mathrm{C}$, followed by centrifugation at $17,000 \mathrm{rpm}$ for $30 \mathrm{~min}$. The pellet was resuspended in a small quantity of buffer $(0.2 M \mathrm{LiCl}, 0.02 M$ Tris, $\mathrm{pH} 7.8$, $\left.10^{-3} \mathrm{M} \mathrm{MgCl}_{2}\right)$ and concentrations determined by absorbance at $260 \mathrm{~nm}\left(A_{260} 1\right.$ $\mathrm{cm} / 1 \%=230)$.

Cell preparation. Single suspensions of spleens were prepared by teasing with a scalpel. The resulting cell suspension was aspirated several times through a syringe, passed through an 80-mesh screen, washed three times in HBSS, subjected to osmotic shock treatment with five volumes of $0.2 \% \mathrm{NaCl}$ for $20 \mathrm{sec}$ to lyse erythro- 
cytes present in the suspension, then immediately diluted 10-fold with BME and centrifuged. The cells were suspended in BME, with $5-20 \%$ calf serum containing penicillin and streptomycin, to a concentration of $10^{7}$ viable cells $/ \mathrm{ml}$. Adherent cells were separated from spleen cell preparations by three, 45 -min culture periods in Falcon plastic petri dishes. The nonadhering cells were decanted after each incubation period into fresh petri dishes. After the final period the nonadhering cells were decanted, centrifuged and resuspended in fresh BME, 5-20\% calf serum at a concentration of $1-1.5 \times 10^{7}$ cells $/ \mathrm{ml}$.

Single-cell suspensions of thymic lymphocytes used to restore thymectomized or irradiated mice were obtained by mincing the thymic lobes of 4-5-week-old $\mathrm{BALB} / \mathrm{Aj}$ mice in cold HBSS containing penicillin, 100 units $/ \mathrm{ml}$. The cell suspension was passed through a No. 80-gauge stainless-steel mesh into HBSS, washed three times, and resuspended in HBSS to appropriate concentrations. Suspensions of bone marrow cells were prepared from 6-9-month-old BALB/Aj mice. The marrow was flushed from femurs and tibias by means of a syringe and a 26-gauge needle containing cold HBSS. The extruded plugs were dispersed by aspiration with a 21-gauge needle, and the cells were washed three times in cold HBSS and resuspended to an appropriate volume.

Thymectomy. Six- to eight-day-old mice were thymectomized according to the method of Sjodin (10). Before removal of spleens for rosette analysis, the mice were examined with the aid of a dissecting microscope for the presence of thymic remnants. Mice with thymic remnants were excluded from the study.

Isotopic labeling procedure. BALB/Aj mice, 9-11 weeks of age were lethally irradiated and $24 \mathrm{hr}$ later reconstituted with various populations of treated or nontreated lymphoid cells. Five days after reconstitution, mice received $8 \mu \mathrm{Ci}$ ip of [methyl $-{ }^{3} \mathrm{H}$ ] thymidine $(15.7 \mathrm{Ci} / \mathrm{mmol}$, Amersham-Searle, Arlington Heights, I11.). Three hours later, all mice were killed quickly by cervical dislocation, and spleens were removed and placed in $5 \mathrm{ml}$ of cold $0.15 \mathrm{M} \mathrm{NaCl}$. Each spleen was homogenized in a glass homogenizer and, without allowing the suspension to settle, triplicate samples $(0.5 \mathrm{ml} / \mathrm{sample})$ were taken and spotted onto Whatman glass-fiber disks. The disks then were washed with $10 \mathrm{ml}$ each of cold $0.15 \mathrm{M} \mathrm{NaCl}$ and $10 \%$ TCA followed by $2-\mathrm{ml}$ washes of $95 \%$ ethanol and absolute ethanol. The disks were dried either overnight in a $37^{\circ} \mathrm{C}$ warm room or $10 \mathrm{~min}$ under an infrarcd light. Dried disks were placed in scintillation vials and $10 \mathrm{ml}$ of purified toluene-PPOPOPOP poured into the vials. Samples were counted on either a Beckman liquid scintillation counter or a New England Nuclear liquid scintillation counter.

Anti- $\theta$ treatment of bone marrow cells. Anti- $\theta$ treatment of bone marrow cells to obtain a pure $B$ cell population was carried out according to the procedure of Neiderhuber (11). Bone marrow cells were obtained as described earlier. After cells were washed three times they were suspended in anti- $\theta$ serum diluted 1:50 at a concentration of $10^{7}$ cells $/ \mathrm{ml}$ of antiserum. (The dilution of antiserum was previously determined by a ${ }^{51} \mathrm{Cr}$ release cytotoxicity study which showed a $1: 400$ dilution to yield $50 \%{ }^{51} \mathrm{Cr}$ release. To insure maximum cytotoxicity it was used eight times more concentrated). The cells plus anti- $\theta$ serum were incubated in a 50-ml screw-cap centrifuge tube, at an angle, for $30 \mathrm{~min}$ at $37^{\circ} \mathrm{C}$ with shaking every $10 \mathrm{~min}$. The cells were centrifuged and washed once in HBSS, after which the washed pellet was suspended at a concentration of $10^{7} \mathrm{cells} / \mathrm{ml}$ in $1: 6$ diluted guinea pig complement, previously absorbed with syngeneic spleen cells and 
agarose. The cells were incubated under the same conditions with the guinea pig complement as with the anti- $\theta$ serum. After a 30 -min incubation at $37^{\circ} \mathrm{C}$, the cells were washed three times in HBSS and counted. As measured by trypan blue exclusion, the cells were $97 \%$ viable.

Passive rosette assay. Nine days after reconstitution, the immune response to HGG was measured by the rosette assay as adapted for protein antigens by Stout (12). Spleens from each experimental group were pooled, dispersed and washed in $\mathrm{PBS}, \mathrm{pH}$ 7.2. SRBC were washed three times in $\mathrm{PBS}, \mathrm{pH}$ 7.2, and resuspended to a $50 \%$ concentration. One-half milliliter of a $100 \mathrm{mg} / \mathrm{ml}$ solution of ECDI [1-ethyl-3-(3-dimethylaminopropyl) carbodiimide- $\mathrm{HCl}$; Ott Chemical Co., Muskegon, Mich.] was added to $3 \mathrm{ml}$ of HGG $(20 \mathrm{mg} / \mathrm{ml})$ and $0.1 \mathrm{ml}$ of $50 \%$ $\mathrm{SRBC}$. The mixture was incubated $50-70 \mathrm{~min}$ at $4^{\circ} \mathrm{C}$, with slow stirring on a magnetic mixer. The cells were centrifuged at $1500 \mathrm{rpm}$ for $10 \mathrm{~min}$, washed twice in $1.0 \%$ normal rabbit serum in PBS, $\mathrm{pH} 7.2$, and finally resuspended to a concentration of $5 \%$. One-tenth milliliter of $5 \%$ SRBC was added to $1 \mathrm{ml}$ of a $5-10 \times 10^{\circ}$ cells $/ \mathrm{ml}$ suspension of spleen cells in a $51 \times 60-\mathrm{mm}$ tube. The tubes were incubated at a $45^{\circ}$ angle for $1 \mathrm{hr}$ and overnight at $4^{\circ} \mathrm{C}$. Rosette-forming cells (RFC) were enumerated by counting the spleen cell-SRBC mixture in a hemocytometer at $200 \times$ magnification. Approximately 20,000-80,000 spleen cells were counted, depending on individual experiments. In all these experiments, rosettes were also determined on nonirradiated mice injected with saline as a positive control of the technique.

It was difficult to obtain results whose absolute values were similar in replicate experiments. This is attributable to the variables in the experimental system and resulting assay. Since the variation from experiment to experiment was great, but the relative differences in RFC between groups within various experiments were fairly constant, statistical analysis was performed on the ratios between groups in most of the experiments rather than on the absolute numbers of RFC. The experiments reported in Tables 2 and 8 permitted analysis of absolute numbers of RFC and are thus reported accordingly. All experiments were performed at least twice.

Determination of plaque-forming cells. The numbers of hemolytic plaques in agar (PFC) were determined by the modification of the method of Jerne by Golub (13). A volume of $0.05 \mathrm{ml}$ of the cell suspension and $0.05 \mathrm{ml}$ of a $14 \%$ suspension of HGG-conjugated SRBC were added to $0.5 \mathrm{ml}$ of $0.5 \%$ agarose solution. The agarose solution was kept at $49^{\circ} \mathrm{C}$ in a water bath prior to the addition of the cells. The mixture was immediately layered on glass slides.

After $1 \mathrm{hr}$ of incubation at $37^{\circ} \mathrm{C}, \mathrm{PFC}$ were developed by incubating slides for $3 \mathrm{hr}$ at $37^{\circ} \mathrm{C}$ on special racks in the presence of guinea pig complement diluted $1: 10$.

\section{RESULTS}

\section{The Effect of Anti-HGG Sera on Macrophage RNA}

Although RNA-rich fractions had been found previously, by isotopic methods, to have less than $10^{-11} \mathrm{~g}$ of antigen per $0.1 \mathrm{mg}$ of RNA (6), the possibility that antigen undetectable by this technique was present and responsible for the specificity of the RNA was investigated by testing whether antiserum to the antigen could negate the capacity of the RNA-rich fraction to induce RFC. 
TABLE 1

Neutralization of Macrophage RNA by Anti-HGG Serum

\begin{tabular}{|c|c|c|c|c|c|}
\hline \multicolumn{2}{|r|}{ Experimental group $^{a}$} & \multicolumn{4}{|c|}{ RFC per $10^{6}$ spleen cells } \\
\hline & & Expt 1 & Expt 2 & Expt 3 & Expt 4 \\
\hline A) & Nonirradiated control & 1,000 & 2,000 & 900 & 700 \\
\hline B) & NASC + n-RNA & 3,200 & 8,200 & 2,800 & 4,200 \\
\hline C) & NASC + RNA:HGG & 8,100 & 20,600 & 6,500 & $\mathrm{ND}^{c}$ \\
\hline D) & NASC + RNA:HGG + NRS & $7,100^{b}$ & 15,400 & 5,600 & ND \\
\hline E) & NASC + RNA:HGG + anti-HGG & 2,300 & 6,600 & 3,100 & 5,600 \\
\hline F) & NASC + RNA:HGG + anti-BSA & $\mathrm{ND}$ & ND & 5,600 & 11,900 \\
\hline
\end{tabular}

a $10^{7} \mathrm{NASC} / 0.1 \mathrm{mg}$ of RNA/0.4 ml of serum (anti-HGG HA titer $=1: 71,360$ ) incubated $1.5 \mathrm{hr}$ at $37^{\circ} \mathrm{C}$. Irradiated mice $(800 \mathrm{R})$ received $10^{7} \mathrm{NASC}$ iv. Spleens were removed on day 9 , pooled and assayed for RFC. Each group represents data obtained from three to five mice Group A served as an uninjected control.

${ }^{b}$ When ratios between Group $\mathrm{E}$ and Group $\mathrm{D}$ for all experiments were evaluated collectively by Student's paired $t$ test, Group E results differed from Group D at $P=0.05$.

${ }^{c} \mathrm{ND}$, not done.

The results (Table 1) demonstrate that anti-HGG does indeed inhibit the rise in RFC elicited by what presumably must be an RNA:HGG complex. This loss was not due to nonspecific serum nucleases as the anti-HGG had a significantly greater effect than the normal rabbit serum (NRS), whose effect was due to the nucleases only. That the response was specific for HGG is shown by Experiments 3 and 4 in Table 1 . When mice were injected with nonadherent spleen cells (NASC) which had been exposed to RNA:HGG plus anti-HGG serum, their ability to produce antibody to $\mathrm{HGG}$ was reduced essentially to that of mice receiving NASC exposed to RNA from normal macrophages ( $\mathrm{n}-\mathrm{RNA}$, Group $\mathrm{E}$ vs $B$ ) and was significantly lower than in mice receiving cells incubated with RNA : HGG (Group C, Expt 3). In contrast, when mice received NASC exposed to RNA : HGG + anti-BSA serum (Group F vs $B$ ), their ability to induce rosetle formation to $\mathrm{HGG}$ was basically unaffected.

Occasionally spleens were assayed for both RFC and PFC to ascertain whether these two procedures gave comparable results. In most cases, as exemplified in Fig.

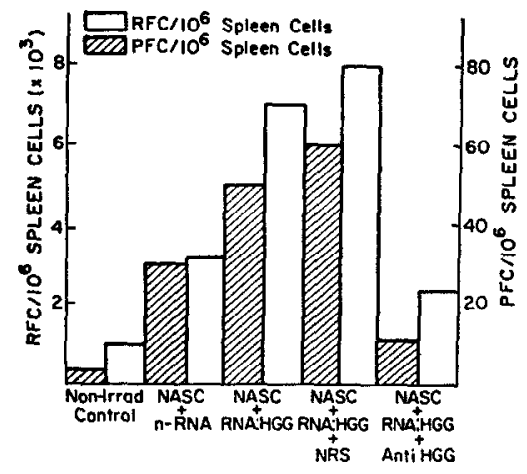

FIG. 1. Comparison of RFC and PFC values in lethally irradiated mice reconstituted with NASC. Irradiated mice $(800 \mathrm{R})$ were injected iv with $10^{7} \mathrm{NASC}$ which had been incubated in vitro for $1.5 \mathrm{hr}$ at $37^{\circ} \mathrm{C}$ with $0.1 \mathrm{mg}$ of RNA and $0.4 \mathrm{ml}$ of serum. Spleens were removed on day 9, pooled and assayed for RFC and PFC. 
TABLE 2

Effect of Various Monospecific Antisera on tile Antibody-Inducing Capability of RNA:HGG

\begin{tabular}{|c|c|c|c|}
\hline \multicolumn{2}{|r|}{ Experimental group ${ }^{n}$} & $\begin{array}{l}\text { RFC per } 10^{6} \\
\text { spleen cells }\end{array}$ & $P$ value $^{b}$ \\
\hline A & Nonirradiated control & $650 \pm 100$ & - \\
\hline B & NASC + n-RNA & $3500 \pm 80$ & $0.01<P<0.05$ \\
\hline $\mathrm{C}$ & NASC + RNA:HGG + NRS & $9950 \pm 2500$ & - \\
\hline $\mathrm{D}$ & $\mathrm{NASC}+\mathrm{RNA}: \mathrm{HGG}+\mathrm{GAGC}^{c}$ & $4650 \pm 290$ & $0.01<P<0.05$ \\
\hline $\mathbf{E}$ & $\mathrm{NASC}+\mathrm{RNA}: \mathrm{HGG}+\mathrm{GAMC}^{\circ}$ & $8750 \pm 2480$ & n.s. ${ }^{d}$ \\
\hline
\end{tabular}

${ }^{a}$ Irradiated mice $(800 \mathrm{R})$ were injected with $10^{7} \mathrm{NASC}$ iv, which had been exposed in vitro to RNA:HGG \pm antiserum (107 NASC/0.1 mg of RNA/0.4 ml of antiserum). Spleens were removed on day 9, pooled and assayed for RFC. Data represent the arithmetic means of results of two experiments, three mice per group.

${ }^{b}$ All groups compared to Group C.

- GAGC, goat anti-IgG ( $\gamma$ chain-specific) serum; GAMC, goat anti-IgM ( $\mu$ chain-specific) serum.

${ }^{\alpha}$ n.s., not significant.

1, the results were comparable but the plaque assay was much less sensitive, giving values about 100 -fold less than $R F C$.

In all experiments it was observed that when mice were irradiated and reconstituted with cells treated with n-RNA, the RFC response was higher than in uninjected, nonirradiated controls. This increase in $\mathrm{RFC}$ response we attribute to the RNA acting as an adjuvant (14) polyclonally on the background response to HGG. Consequently mice receiving n-RNA-treated cells constituted the control group to which experimental groups were always compared. The uninjected group is included in the tables only as a control on the technique and the background response of the particular group of mice under investigation.

\section{Nature of the Antigen Complexed to Macrophage RNA}

The presence of antigenic fragments remaining on macrophage membranes (5) as well as associated with oligoribonucleopeptides in spleen and lymph nodes has been reported (15).

The possibility that the antigen present in our RNA preparation might be only a part of the $\gamma$-globulin molectule was considered. When NASC were exposed in vitro to RNA : HGG and either NRS or monospecific anti-human IgM (anti- $\mu$ ) was included in the mixture, the spleen cells were able to induce antibody formation to HGG when injected into lethally irradiated mice (Table 2). In contrast, when monospecific anti-human IgG (anti- $\gamma$ ) was substituted for either NRS or monospecific IgM, the ability of the NASC to induce antibody formation to IIGG in vivo was reduced significantly. Utilizing antiserum specific for either $\kappa$ or $\lambda$ light chain in a single experiment with the same type of experimental design as cited above, values of 2600 or $6100 \mathrm{RFC}$, respectively, were obtained as compared to 3800 for NASC + n-RNA and 8100 for NASC + RNA:HGG + NRS, thus hinting that $\kappa$ chains were present on the RNA-rich fractions. These data are interpreted as evidence that the fragment of antigen on the RNA:HGG consists of at least part of the $\gamma$ heavy chain and $\kappa$ light chain. 
TABLE 3

Amility of Macrophage RNA to Replace Need for Adherent Cell

\begin{tabular}{lccc}
\hline \multirow{2}{*}{ Experimental group } & & \multicolumn{3}{c}{${\text { RFC per } 10^{6} \text { spleen cells }}$} & Expt 2 & Expt 3 \\
\cline { 2 - 4 } & Expt 1 & 1000 & 400 \\
Nonirradiated control & 100 & 1000 & 1600 \\
NASC + n-RNA & 2500 & 3200 & 3800 \\
NASC + RNA:HGG & $7100^{b}$ & 7100 & \\
\hline
\end{tabular}

${ }^{a}$ Irradiated mice $(800 \mathrm{R})$ received $10^{7} \mathrm{NASC}$ (treated as in Table 1 ). Nine days after reconstitution mice were sacrificed and spleens assayed for RFC. Each group represents data of spleens pooled from four or five mice.

${ }^{b}$ When ratios between Group 3 and 2 (Expt 1-3) were evaluated collectively by Student's paired $t$ test, Group 3 results differ significantly from Group 2 results at $P=0.01$.

Cellular Requirement for Antibody Formation to HGG in Reconstituted Lethally Irradiated Mice

In three preliminary experiments both the adherent and nonadherent cells were found to be required for antibody production to $\mathrm{HGG}$ in our control system. However, when RNA: HGG was incubated for $1.5-2 \mathrm{hr}$ with either nonadherent cells alone or a mixture of nonadherent and adherent cells and injected subsequently into lethally irradiated $(800 \mathrm{R})$ syngeneic mice, it was apparent (Table 3 ) that the adherent cell population was not needed by the RNA:HGG complex for induction of RFC.

\section{Induction of Antibody Formation in B Cells by RNA:HGG}

Since RNA: HGG could induce antibody formation in NASC, abrogating the need for the adherent cell, it was of importance to determine whether the interaction required both $T$ and $B$ cells. Accordingly, mice were lethally irradiated and $24 \mathrm{hr}$ later reconstituted with $\mathrm{T}$ and $\mathrm{B}$ cells that had been exposed in vitro singly or collectively to either n-RNA or RNA: HGG. Table 4 shows that when $T$ and $B$

TARI.F. 4

Rosette Formation by B Cells Exposed to RNA:HGGa

\begin{tabular}{|c|c|c|}
\hline \multicolumn{2}{|c|}{ Inoculum } & \multirow{2}{*}{$\begin{array}{l}\text { RFC per } 10^{6} \\
\text { spleen cells }\end{array}$} \\
\hline Day 0 & Day 1 & \\
\hline Nonirradiated & - & 800 \\
\hline $\mathrm{T}+\mathrm{B}+\mathrm{n}-\mathrm{RNA}$ & - & 3200 \\
\hline $\mathrm{T}+\mathrm{B}+\mathrm{RNA}: \mathrm{HGG}$ & - & 6100 \\
\hline $\mathrm{T}+\mathrm{RNA}: \mathrm{HGG}$ & $\mathrm{B}$ & 2100 \\
\hline $\mathrm{B}+\mathrm{RNA}: \mathrm{HGG}$ & $\mathrm{T}$ & 5500 \\
\hline
\end{tabular}

a Irradiated mice $(800 \mathrm{R})$ received either $4 \times 10^{7}$ thymus $(\mathrm{T})$ cells plus $10^{7}$ bone marrow (B) cells that had been incubated in vitro with $\mathrm{n}$-RNA or RNA:HGG $\left(4 \times 10^{7} \mathrm{~T}\right.$ cells $/ 10^{7} \mathrm{~B}$ cells $/ 0.1$ $\mathrm{mg}$ of $\mathrm{RNA} / \mathrm{ml}$ of $\mathrm{BME}$ ), or they received only one population of the cells that had been exposed to RNA:HGG (107 $\mathrm{B}$ cells $/ 0.1 \mathrm{mg}$ of $\mathrm{RNA}$ or $4 \times 10^{7} \mathrm{~T}$ cells $/ 0.1 \mathrm{mg}$ of RNA) and the next day received the population not exposed to RNA:HGG. Spleens were removed on day 10, pooled and assayed for RFC. Each group represents three to five mice. 
TABLE 5

Ability of RNA:HGG to Induce Anti-ligG Antibody Formation in B Cellos Directly ${ }^{a}$

\begin{tabular}{lccc}
\hline \multirow{2}{*}{ Experimental group } & \multicolumn{3}{c}{ RFC per $10^{6}$ spleen cells } \\
\cline { 2 - 4 } & Expt 1 & Expt 2 & Expt 3 \\
\hline Nonirradiated control & 1100 & 700 & 900 \\
T + B + n-RNA & 2700 & 3900 & 4300 \\
T + B + RNA:HGG & 4000 & ND & 8100 \\
B + RNA:HGG & $6800^{b}$ & 9700 & 9300 \\
B + HGG & ND $^{c}$ & ND & 4200 \\
\hline
\end{tabular}

${ }^{a}$ Irradiated mice $(800 \mathrm{R})$ received $4 \times 10^{7} \mathrm{~T}$ cells $+10^{7} \mathrm{~B}$ cells iv, exposed in vitro to RNA $(0.1 \mathrm{mg})$ for $1.5 \mathrm{hr}$, or they received only $10^{7} \mathrm{~B}$ cells previously incubated with RNA:HGG $\left(10^{7} \mathrm{~B}\right.$ cells $/ 0.5 \mathrm{mg}$ of $\left.\mathrm{HGG} / \mathrm{ml}\right)$. Nine days after reconstitution, spleens were removed, pooled and assayed for RFC. Each group represents three or four mice.

${ }^{b}$ When ratios between $B+R N A$ :HGG groups and $T+B+n-R N A$ groups were evaluated together (Expt 1-3) by Student's paired $t$ test, the data from the B + RNA:HGG groups together differed from the T $+\mathrm{B}+\mathrm{RNA}: \mathrm{HGG}$ group at $P<0.01$.

ND, not done.

cells collectively had been exposed to RNA:HGG they induced a significantly higher antibody response to $\mathrm{HGG}$, as measured by $\mathrm{RFC}$, than cells exposed to n-RNA. When irradiated mice were reconstituted with a single population of either $\mathrm{T}$ or $\mathrm{B}$ cells exposed to RNA : HGG followed $24-48 \mathrm{hr}$ later by injection of the population of lymphoid cells not previously infused, $B$ cells alone appeared to be capable of responding directly to RNA : HGG.

To confirm this contention, lethally irradiated mice $(800 \mathrm{R})$ were injected $24 \mathrm{hr}$ after irradiation with $4 \times 10^{7} \mathrm{~T}$ cells and $10^{7} \mathrm{~B}$ cells that had been incubated in vitro with either $\mathrm{n}-\mathrm{RNA}$ or $\mathrm{RNA}: \mathrm{HGG}$, or they received only $10^{7} \mathrm{~B}$ cells without $T$ cells. Results of these studies can be seen in Table 5 . When $B$ cells alone were exposed to RNA : HGG and injected into lethally irradiated syngeneic mice, the antibody response to $\mathrm{HGG}$ was about two and a half times greater than the response in mice which received $T$ and $B$ cells exposed to n-RNA. In Experiment 3 (Table 5 ) when mice received $B$ cells that had been exposed to $H G G$, the $\mathrm{RFC}$ response of $4200 \mathrm{RFC} / 10^{6}$ spleen cells was the same as the control group that received normal RNA-treated cells. However, mice that received $\mathrm{B}$ cells treated with RNA : HGG produced a response greater than twice that of the control group.

Induction of Anti-HGG Antibody by RNA:HGG in Thymeclomized Irradialed Mice Restored with Anti- $\theta$-Treated B Cells

From the preceding data it was suggested that RNA:IIGG was capable of inducing $B$ cells to form rosettes in the absence of $T$ cells. However, inasmuch as a small population of $T$ cells may be sequestered in bone marrow (16), more definitive evidence for RNA : HGG being a T-independent antigen was required.

Accordingly, 6-8-day-old mice were thymectomized. Four weeks after thymectomy these mice were irradiated ( $800 \mathrm{R}$ ) and $24 \mathrm{hr}$ later they were reconstituted with either $\mathrm{T}$ and $\mathrm{B}$ cells or $\mathrm{B}$ cells alone. In both cases cells were incubated with RNA : HGG and the $B$ cells were treated with anti- $\theta$ serum and $C^{\prime}$ to reduce the 
TABLE 6

Antibody Formation in Thymectomized Irradiated Mice Reconstitutid with Anti- $\theta$-Treated Bone Marrow Cellos ${ }^{a}$

\begin{tabular}{lcc}
\hline $\begin{array}{c}\text { Inuculum } \\
\text { (incubated } \text { in vitro) }\end{array}$ & \multicolumn{2}{c}{ RFC per 10 $0^{6}$ spleen cells } \\
\cline { 2 - 3 } & Expt 1 & Expt 2 \\
\hline Nonirradiated control & 800 & 500 \\
B + HGG & 2800 & 1300 \\
B + n-RNA & 3900 & 3300 \\
B + RNA:HGG & $8500^{b}$ & 8000 \\
B + T + RNA:HGG & ND $^{c}$ & 4400 \\
\hline
\end{tabular}

a Thymectomized, irradiated ( $800 \mathrm{R}$ ) mice received $10^{7} \mathrm{~B}$ cells (anti- $\theta+\mathrm{C}^{\prime}$ treated) that were incubated in vitro $(1.5 \mathrm{hr})$ with $\mathrm{RNA}\left(10^{7} \mathrm{~B}\right.$ cells $/ 0.1 \mathrm{mg}$ of $\left.\mathrm{RNA} / \mathrm{ml}\right)$, or they received $4 \times 10^{7} \mathrm{~B}$ cells exposed to RNA under the same conditions as $B$ cells alone $\left(10^{7} \mathrm{~B}\right.$ cells $/ 0.1 \mathrm{mg}$ of $\left.\mathrm{RNA} / \mathrm{ml}\right)$. Nine days after reconstitution mice were sacrificed, spleens removed, and assayed for RFC. Each value represents pooled data from three or four mice.

${ }^{b}$ When the ratios between B + RNA:HGG groups and B + n-RNA groups were evaluated collectively by Student's $t$ test, the results of the B + RNA:HGG groups together differed from the data of the $\mathrm{B}+\mathrm{n}-\mathrm{RNA}$ groups at $P=0.05$.

ND, not done.

number of $\mathrm{T}$ cells which might be present in the bone marrow cell preparation. Mice receiving $B$ cells that had been incubated with RNA:HGG produced a significantly higher $R F C$ response than mice receiving $B$ cells exposed to $n-R N A$, as can be seen in Table 6. Also, as was the case in earlier studies, HGG alone was unable to stimulate $B$ cells to produce antibody. When $T$ cells were added to the incubation mixture they seemed to suppress the antibody response. Thus, these and repeat experiments provided evidence that the complexing of antigen to an RNA-rich fraction from macrophages converts $\mathrm{HGG}$ from a $\mathrm{T}$ cell-dependent antigen to a $T$ cell-independent antigen.

TABLE 7

Effect of Adjuvants on the Antibody-Inducing Abilify of RNA:HGG ${ }^{a}$

\begin{tabular}{lccc}
\hline & \multicolumn{3}{c}{ RFC per 106 spleen cells } \\
\cline { 2 - 4 } & Expt 1 & Expt 2 & Expt 3 \\
\hline Nonirradiated mice & 1100 & 900 & 1100 \\
T + B only & 3400 & ND & ND \\
T + B + N-RNA & ND & ND & 5100 \\
T + B + RNA:HGG & 7300 & 6500 & 10,200 \\
T + B + RNA:HGG + endotoxin & 9800 & 13,600 & 15,300 \\
T + B + RNA:HGG + poly (A:U) & ND & ND & 10,400 \\
\hline
\end{tabular}

${ }^{a}$ Concentrations for incubation: $4 \times 10^{7} \mathrm{~T}$ cells $/ 10^{7} \mathrm{~B}$ cells $/ 0.1 \mathrm{mg}$ of RNA $/ 300 \mu \mathrm{g}$ of poly (A:U) or $10 \mu \mathrm{g}$ of endotoxin $/ \mathrm{ml}$. Irradiated mice received $0.5 \mathrm{ml}$ of cells iv containing $4 \times 10^{7} \mathrm{~T}$ cells and $10^{7} \mathrm{~B}$ cells previously incubated with the specified additives in proportions as specified. Nine days after reconstitution spleens were removed and assayed for RFC. Each group represents data pooled from three mice.

${ }^{b} \mathrm{ND}$, not done. 
Effect of Adjuvants on the Ability of RNA:HGG to Induce Antibody Formation in $T$ and $B$ Cells

Previous studies have shown that the homoribopolymer complex of poly (A:U) manifests its adjuvant action partly by acting on antigen reactive cells of thymus origin (7). Likewise, it is well established that endotoxin (LPS) acts primarily on $B$ cells. Consequently, if RNA : HGG were T cell-independent, poly (A : U) should not have an effect on the antibody-inducing ability of RNA : HGG. In contrast, if RNA : HGG were acting on the B cell, LPS should enhance the response. As seen in Table 7, when mice received cells that had been incubated with RNA: HGG and endotoxin, significant elevations in RFC were observed as compared to mice receiving cells exposed only to RNA:HGG. The data supported the $T$ cell independence of RNA : HGG in that the number of $\mathrm{RFC}$ in mice that received cells incubated with RNA:HGG and poly (A:U) failed to show any significant increase in RFC in three repeat experiments (data not shown).

\section{Effect on RNA:HGG on DNA Synthesis in B Cells}

Since Coutinho and Moller (18) showed that all thymus-independent antigens tested possessed mitogenic properties for B cells, RNA: HGG was examined for this property.

Mice were irradiated and reconstituted with $B$ or $T$ cell populations that had been exposed to RNA : HGG. Five days after reconstitution the mice were injected ip with $8 \mu \mathrm{Ci}$ of $\left[{ }^{3} \mathrm{H}\right]$ thymidine; $3 \mathrm{hr}$ later each individual mouse spleen was assayed for radioactivity in triplicate samples. The results of these experiments are reported in Table 8 . Since the RNA was slightly toxic to cells during in vitro incubation, the n-RNA-treated cells once again must serve as a control for groups receiving RNA : HGG-treated cells. The B-cell-only or T-cell-only groups served as controls only for mice that received cells exposed to HGG. Mice receiving B cells incubated

TABLE 8

EfFect of RNA:HGG on DNA Synthesis in T ANd B Cells ${ }^{a}$

\begin{tabular}{lcccr}
\hline Cell mixture injected & \multicolumn{2}{c}{$\left.{ }^{3} \mathrm{H}\right]$ Thymidine uptake (cpm (mean of triplicate samples) $\pm \mathrm{SE}$ ) } \\
\cline { 2 - 5 } & Expt 1 & Expt 2 & Expt 3 & Expt 4 \\
\hline Nonirradiated control & $1,200 \pm 363$ & $6,000 \pm 228$ & $1,443 \pm 130$ & $3,533 \pm 704$ \\
B cells only & ND $^{b}$ & $4,700 \pm 140$ & ND & $3,974 \pm 916$ \\
B + HGG & ND & $3,300 \pm 725$ & ND & $4,889 \pm 512$ \\
B + n-RNA & $1,100+115$ & $650 \pm 289$ & ND & $6,186 \pm 778$ \\
B + RNA:HGG & $13,300 \pm 306$ & $5,350 \pm 409$ & $1,332 \pm 610$ & $13,798 \pm 415$ \\
T cells only & ND & ND & $51 \pm 12$ & $444 \pm 34$ \\
T + HGG & ND & ND & $94 \pm 5$ & $544 \pm 109$ \\
T + n-RNA & ND & ND & $84 \pm 20$ & $296 \pm 34$ \\
T + RNA:HGG & ND & ND & $54 \pm 14$ & $230 \pm$ \\
\hline
\end{tabular}

a Irradiated mice received either $10^{7} \mathrm{~B}$ cells or $4 \times 10^{7} \mathrm{~T}$ cells iv that had previously been incubated with either $0.5 \mathrm{mg}$ of $\mathrm{HGG}$ or $0.1 \mathrm{mg}$ of RNA. Five days afterward they received $8 \mu \mathrm{Ci}$ of $\left[{ }^{3} \mathrm{H}\right]$ thymidine ip. Three hours later all spleens were removed and assayed for radioactivity. Each value represents the mean of data from three mice.

${ }^{b} \mathrm{ND}$, not done. 
with RNA:HGG showed a significant uptake of $\left[{ }^{3} \mathrm{H}\right]$ thymidine over mice receiving cells treated with $\mathrm{n}$ - $\mathrm{RNA}$. In contrast, no difference was apparent between groups which received B cells only or B cells + HGG. Thus, in keeping with its known thymus dependency, HGG alone, in contrast to RNA: HGG, did not stimulate $B$ cells to increased DNA synthesis. Again, RNA: HGG had no effect on $\mathrm{T}$ cells.

\section{DISCUSSION}

The nature of the active complex was an important initial question in this investigation. Earlier studies in this laboratory had shown that the ability of this 4S macrophage RNA to induce an immune response was RNase sensitive (6), indicating that RNA was an essential component. In the results reported herein, it may be seen that the addition of anti-HGG serum to the RNA from HGGsensitized macrophages abrogated the ability to induce rosette formation in the nonadherent spleen cell suspension. Since normal rabbit serum had no effect in the same system, it can be inferred that the loss of antibody-inducing ability was due to a specific neutralizing effect by the anti-HGG serum and not to nucleases present in the antiserum. The specificity of the effect was supported further by the demonstration that antiserum to non-cross-reacting antigen (BSA) had no effect on the RNA: HGG. Thus, the presence of HGG in the RNA moiety, albeit in very small amount, is implicated also. Inasmuch as antiserum to human $\kappa$ and $\gamma$ chains neutralized the ability of RNA : HGG to induce antibody formation, it is surmised that both heavy and light chains were present. Whether an intact immunoglobulin molecule or only a fragment is present cannot be ascertained from these data. However, the amount of antigen present in the RNA was insufficient by itself to initiate an antibody response; consequently, the RNA must in some way serve as an adjuvant for the antigen. It is interesting to note in this connection that polynucleotides have been shown to stimulate antibody formation to as little as $1 \mathrm{ng}$ of bovine $\gamma$-globulin (19).

The second significant finding of this study, that the RNA : HGG was able to induce B spleen cells to produce antibody directly, thus overriding the need for the adherent cell and the $\mathrm{T}$ cell, is in disagreement with the finding of Meiss and Fishman (20). They found that T2 phage RNA needed both the adherent cell and the nonadherent cell for antibody to T2 phage to be produced in vitro. However, more recently, Adler et al. (21) have used both soluble and intact T2 phage and found the solubilized phage to be more immunogenic than intact phage in spleen cell cultures. In vivo, no difference in immunogenicity was observed between the two antigenic forms, which was attributed to the presence of macrophages and their ability to solubilze the phage. It is known that $\mathrm{X}$-irradiation, which was employed in our design, does not kill all adherent cells in vivo (22). Consequently, the RNA concievably could activate the remaining macrophages present, as Evans and Alexander have demonstrated (23), resulting in our model in vivo actually equating with the in vitro model of Meiss and Fishman (20). In addition, it should be pointed out that the above two systems measured antibody formation in vitro with a particulate antigen, while a soluble antigen and in vivo RFC production was measured in our study. Thus, the determining factor as to whether the adherent cell is needed might likely depend on the molecular form or degree of solubilization of the antigen. 
Recent findings on $\mathrm{B}$ cell activation offer several possible interpretations of our finding that an RNA-rich moiety was able to convert the antigenic fragment complexed to it from a thymus-dependent antigen to a thymus-independent antigen. In vitro studies have been interpreted as indicating that the critical factor in $\mathrm{B}$ cell activation by both thymus-dependent and thymus-independent antigens is presentation of antigenic determinants in a multivalent configuration of suitable epitope density (24). Thus, antigen in a molecular form that does not require further solubilization or assistance in obtaining proper antigenic determinant presentation to the $\mathrm{B}$ cell circumvents the need for the macrophage. Perhaps RNA : HGG and the detergent-solubilized T2 phage of Adler et al. (21) fit such specifications, whereas the particulate T2 phage RNA does not.

Second, it has been proposed that $B$ cell activation may require two separate signals, a nonspecific one coming from either a $\mathrm{T}$ cell product (25) or a factor released by the macrophage (26) and a second specific signal being supplied by antigen. One nonspecific signal for $B$ cell activation may be provided by the interaction of the complement component $C_{3} \mathrm{~b}$ with the $B$ cell surface (27). Hadding et al. (28) have shown that dextran sulfate, a polyanion mitogenic for $B$ cells, activated $C_{3}$ proactivator and $C_{3}$. Thus, dextran sulfate might manifest its mitogenic activity through activation of $\mathrm{C}_{3}$, and it is conceivable that the RNA portion of the RNA: HGG might activate $\mathrm{C}_{3}$ also. However, Coutinho et al. (29) have presented convincing evidence for only one signal being required for the cell to begin antibody synthesis. In their system, mitogens supplied the actual signal, with antigen serving only to focus that signal on the specific $B$ cell. T-independent antigens were shown to possess within one molecule both the nonspecific mitogenic signal for B cells and the specific antigenic focuser (30). With the recent documentation of the mitogenic properties of polyanions and polynucleotides $(14,31)$, we hypothesize from our data that an RNA-rich fraction isolated from HGGsensitized macrophages has complexed to it a residual HGG molecule. The mitogenic property of this RNA endows the complex with the ability to directly activate the $\mathrm{B}$ cell to produce anti-HGG antibody following specific localization of this signal by the HGG fragment. Vaccination with like antigen-RNA complexes might be a useful approach to circumventing the difficulty in patients with thymic hypoplasia or as an adjuvant to weak tumor antigens (cf. Ref. (4)).

\section{REFERENCES}

1. Gottlieb, A. A., and Schwartz, R. H., Cell. Immunol. 5, 341, 1972.

2. Roelants, G., and Goodman, J., J. Exp. Med. 130, 557, 1969.

3. Adler, F., Fishman, M., and Dray, S., J. Immunol. 97, 554, 1968.

4. Pilch, Y. H., and Ramming, K. P., Cancer 26, 630, 1970.

5. Unanue, E. R., Advan. Immunol. 15, 95, 1972.

6. Johnson, H., and Johnson, A. G., J. Exp. Med. 133, 649, 1971.

7. Merritt, K., and Johnson, A. G., J. Immunol. 94, 416, 1965.

8. Reif, A. E., and Allen, J. M., Nature (London) 209, 521, 1966.

9. Gallily, R., and Feldman, M., Immunology 12, 197, 1967.

10. Sjodin, L., Dalmasso, A. P., Smith, J. M., and Martinez, C., Transplantation 1, 521, 1963.

11. Niederhuber, J. E., and Möller, E., Cell. Immunol. 3, 559, 1972.

12. Stout, R. D., and Johnson, A. G., J. Exp. Med. 135, 45, 1972.

13. Golub, E. S., Mishell, R. I., Weigle, W. O., and Dutton, R. W., J. Immunol. 100, 133, 1968.

14. Diamanstein, T., Vogt, W., Rühl, H., and Bochert, G., Eur. J. Immunol. 3, 488, 1973. 
15. Yuan, L., and Campbell, D. H., Immunochemistry 8, 185, 1971.

16. Cohen, J. J., J. Immunol. 108, 841, 1972.

17. Cone, R. E., and Johnson, A. G., J. Exp. Med. 133, 665, 1971.

18. Coutinho, A., and Möller, G., Nature New Biol. 245, 12, 1973.

19. Schmidtke, J. R., and Johnson, A. G., J. Immunol. 106, 1191, 1971.

20. Meiss, H. K., and Fishman, M., J. Immunol. 108, 1172, 1972.

21. Adler, L., Curley, D. M., and Fishman, M., J. Immunol. 110, 811, 1973.

22. Taliaferro, W. H., Taliaferro, L. G., and Jaroslow, D. N., "Radiation and Immune Mechanisms." Academic Press, New York, 1964.

23. Evans, R., and Alexander, P., Nature New Biol. 232, 76, 1971.

24. Katz, D., and Unanue, E. R., J. Exp. Med. 137, 967, 1973.

25. Gorczynski, R. M., Miller, R. G., and Phillips, R. A., J. Immunol. 108, 457, 1972.

26. Schrader, J. W., J. Exp. Med. 137, 844, 1973.

27. Dukor, P., and Hartman, K. U., Cell. Immunol. 7, 349, 1973.

28. IJadding, U., Dierich, M., Konig, W., Limbert, M., Scholemmer, H. U., and BitterSuermann, D., Eur. J. Immunol. 3, 527, 1973.

29. Coutinho, A., Gronowicz, E., Bullock, W., and Möller, G., J. Exp. Med. 139, 74, 1974.

30. Coutinho, A., and Möller, G., Nature New Biol. 245, 12, 1973.

31. Johnson, A. G., and Han, I. H., In "Cyclic AMP, Cell Growth, and the Immune Response" (W. Braun, L. M. Lichtenstein, and C. W. Parker, Eds.), p. 77. Springer-Verlag, New York. 